\title{
Cooperative Development Gap in Québec and Saskatchewan 1980 to 2010: A Tale of Two Movements
}

\section{Mitch Diamantopoulos}

University of Regina

\begin{abstract}
This study uses Gramscian hegemony theory and the social movement approach to cooperative development to investigate the cooperative development gap that opened up between the provinces of Québec and Saskatchewan from 1980 to 2010. First, provincial sector growth is compared across several indices to establish this gap's empirical scope and scale. Second, historical research and fieldwork findings are used to illuminate the gap's origins and its historical significance. The article concludes that the development gap has been largely driven by bloc formation and dissolution-the historic erosion of Saskatchewan's traditional, agrarian-cooperative bloc and the renewal and expansion of Québec's social economy bloc.
\end{abstract}

\section{RÉSUMÉ}

Cette étude utilise la théorie de l'hégémonie de Gramsci et la méthode par le mouvement social pour le développement des coopératives afin d'enquêter sur l'écart qui s'est creusé entre les provinces du Québec et de la Saskatchewan de 1980 à 2010 en ce qui a trait au développement des coopératives. Tout d'abord, pour établir la portée et l'échelle empiriques de cet écart, cette étude compare la croissance de ce secteur entre les deux provinces. Ensuite, l'origine de l'écart et sa signification historique sont mis en lumière grâce aux recherches historiques et aux conclusions tirées de l'étude sur le terrain. Finalement, il est conclut dans cet article que l'écart de développement a été majoritairement créé par la formation et la dissolution de blocs l'érosion par le temps du bloc coopératif agraire traditionnel de la Saskatchewan ainsi que le renouveau et l'expansion du bloc d'économie sociale du Québec.

Keywords / Mots clés Social innovation; Cooperatives; Social movements; Social economy; Economic Democracy; Gramsci; Historical bloc; Hegemony; Saskatchewan; Québec / Innovation sociale; Coopératives; mouvements sociaux; Économie sociale; Démocratie économique; Gramsci; Bloc historique; Hégémonie; Saskatchewan; Québec 


\section{Diamantopoulos (2011)}

\section{INTRODUCTION: MAKING SENSE OF GLOBALIZATION ERA CO-OPERATION}

The 1980s ushered in a volatile period of global market restructuring and neo-liberal policy reform (Marchak, 1991). It also signalled a brave new world of structural instability for Canadian cooperatives. As businesses, many had to adjust to new competitive and regulatory environments. As democratic associations, all Canadian cooperatives contended with fundamental shifts in the social, cultural, and political terrains on which they found themselves manoeuvring (Coleman, 2004). This was a significant and turbulent transition in the history of Canadian co-operation-filled with promise, peril, and lessons for the future.

Paradoxically, while vast sections of Saskatchewan's movement would go bust in the wake of globalizationwith de-mutualizations in dairy, poultry, and grains (Fulton and Hueth, 2009), co-operation in Québec boomed. The province doubled its number of cooperatives-which had been a century in the making-in only two decades (Co-operatives Secretariat, 1986; 2006). This study compares these dramatically contrasting experiences, presenting evidence of the "cooperative development gap" that opened up between these provinces, and discussing the roots of their contradictory development paths. Drawing on Gramsci's (1971a) theory of ideological hegemony, these cases are analyzed in terms of the development coalitions or "historical blocs" underpinning these movements-agrarian, disarticulated, and eroding in the case of Saskatchewan but urbanized, renewed, and expanding in Québec.

However, this study's implications go well beyond these provinces. With Saskatchewan lagging the national average by an almost 6:1 ratio in new cooperative formations from 1985 to 2005 but Québec more than doubling pan-Canadian performance (Co-operatives Secretariat, 1987; 2008), these movements now represent opposite extremes-they are outlier cases of extraordinary movement degeneration and regeneration respectively. Their dramatically diverging fortunes in the globalization era thus also present a natural experiment for investigating why-in some times, places, and stages in their life-cycles-some cooperative movements decline while others prosper.

\section{THEORY AND METHODS}

This study's objective is thus two-fold: to establish the empirical scope, scale, and pace of movement divergence; and to assess the role of bloc formation (and dissolution) in this development gap.

Mixed methods are employed. First, cross-provincial, baseline data are used to compare trends in the number of cooperatives and their memberships, revenues, and assets. The study also compares twenty- and five-year trends-to gauge the accelerating pace of divergence. Nation-wide "Top Fifty" rankings index the role of dominant players in overall movement resilience while the growth of emerging service cooperative sectors benchmark the movements' evolving capacity to innovate, broaden-out, and regenerate. Since quantitative measures can describe but not explain this gap, historical research and fieldwork findings-based on 27 interviews in Québec and Saskatchewan conducted during 2009 and 2010-further explore its historical significance.

Theoretically, this study draws on the social movement approach to cooperative development (Develtere, 1996; Fairbairn, 2001). Develtere (1996) argues "co-operatives cannot be analyzed as distinct social movements," because "it is (their) relationship with other social movements which to a great extent accounts for the diversity and scale of co-operative activity" (p. 28). For example, parent movements or patrons may be religious, nationalist, farmer-based, labour-led, or socialist. In this conception, the development potential of cooperative 


\section{Diamantopoulos (2011)}

movements will rise and fall with the mobilizing potential of their extended social movement families. Indeed, Fairbairn (1994) argues that wider social movement ties nurtured the very roots of the modern cooperative movement:

It is ... reasonable to say that the forces of poverty and need inspired the formation of the Rochdale cooperative. But they did so somewhat indirectly, mediated by the agency of idealism and critical social thought, and by the activists of Owenism, Chartism, and other social movements. The Rochdale Pioneers did not rise spontaneously from need, but were organized consciously by thinkers, activists, and leaders who functioned within a network of ideas and institutions. The same can probably be said of all successful co-operatives in all times and places: they arise from need-when some activists, institutions, or agencies consciously promote and organize them. (p. 4)

This article's emphasis on the role of social movements in the construction of viable cooperative blocs rejects economic determinism (Gramsci, 1971a), and the notion that globalization is a monolithic, market-driven process with universal, mechanical, or predictable consequences for co-operation. Instead economic life is viewed as also shaped by the social action of actively contending and evolving historical blocs. Carroll and Ratner (1989) define an "historical bloc" as "a strategic alignment of classes, class fractions and popular groupings whose interests and outlook are realized within the project and whose coalescence establishes an organic relation between (the economic) base and (the ideological-cultural) superstructure" (p. 30).

A Gramscian approach thus re-centres movement agency-what George Keen called the "associative intelligence" (cited in MacPherson, 1979, p. 28) of popular movements. It emphasizes the deep social embeddedness of democratic economic action (Granovetter, 1992; Bourdieu, 2005), including the vital role of ties to the extended social movement families of 'co-operation' (Develterre, 1996; Fairbairn, 2001), and activists' efforts to articulate a coherent and compelling vision that can unify and mobilize an historic bloc.

For example, a Gramscian approach enables us to better understand the embeddedness of early cooperative movements in historical blocs: on the Prairies, it situates the campaign for wheat pooling under agrarian settler hegemony, the farmers' movement, and the emergence of agrarian socialism (Lipset, 1959); in Québec, it highlights clerical hegemony, petit-bourgeois anti-urbanism, and defensive nationalism in the early strivings of the Mouvement Desjardins. As this study demonstrates, movement fates continue to rest on the erosion or renovation of the historical blocs within which they are embedded (Vaillancourt, 2009).

\section{MEASURING THE COOPERATIVE DEVELOPMENT GAP}

\section{Established sector strengths}

Since Québec's population dwarfs Saskatchewan's by a ratio of about 7.5:1, per capita figures provide more meaningful comparisons. Table 1 compares each sector's contribution to its provincial economy in 2007. While Saskatchewan's consumer-dominated movement generates 50\% more jobs than Québec, as a share of their provincial labour forces, Québec's sector is led by long-established and enduring agricultural cooperatives. Its financial services giant, Desjardins, also has a three decade head start on Saskatchewan's credit unions. As a result, the Québec movement has accumulated 73\% more working capital than Saskatchewan's on a per capita basis. Far from marginal curiosities-and despite the globalization-era de-mutualizations of leading Prairie agricultural cooperatives like the Saskatchewan Wheat Pool (SWP or the Pool), DairyWorld, and Lilydale (Fulton and Hueth, 2009) and the collapse of Québec's industrial credit union (caisse d'économie), fishery, and 


\section{Diamantopoulos (2011)}

consumer cooperative federations (Lévesque, 1990)—these movements continue to provide significant foundations for their provinces' mixed economies. Québec's sector generates over double the pan-Canadian movement's employment as a share of its total labour market. Saskatchewan generates triple the nation-wide proportion. Similarly, Québec has generated almost double the per capita wealth built up by the movement nation-wide. Saskatchewan has created well over double the cross-Canada per capita share.

Table 1. Total cooperative sector comparison: Québec, Saskatchewan, and Canada, 2007

\begin{tabular}{|l|r|r|r|}
\hline & \multicolumn{1}{|c|}{ Québec } & Saskatchewan & \multicolumn{1}{c|}{ Canada } \\
\hline Jobs (2007) & 73,846 & 14,409 & 142,928 \\
\hline $\begin{array}{l}\text { Jobs per capita (total labour } \\
\text { force, seasonally adjusted) }\end{array}$ & .02 & .03 & .008 \\
\hline \multicolumn{1}{|c|}{ Assets (2007) } & $\$ 99.7$ billion & $\$ 15.6$ billion & $\$ 228$ billion \\
\hline Assets per capita & $\$ 12,969$ & $\$ 15,600$ & $\$ 6,924$ \\
\hline
\end{tabular}

\section{Non-financial cooperatives}

A comparison of Canada's top fifty non-financial cooperatives from 2007 further indicates established sector strength in Québec and Saskatchewan (see Table 2). Of Canada's leading cooperatives, Saskatchewan accounts for seven (or $14 \%$ ) of the top tier cooperatives. Québec accounts for 13 or (26\%). While the combined populations of these provinces account for only $26 \%$ of the nation's overall population, their cooperatives comprise a full $40 \%$ of the nation's top 50 non-financial cooperatives. The development paths of these cooperative provinces diverge sharply from pan-Canadian norms. The location of top ranked cooperatives drives considerably greater sector employment, revenue, and wealth creation in these provinces. These historic achievements have also established a stronger hegemonic position for cooperative enterprise in the political and economic cultures of these provinces.

Table 2. Top 50 Non-financial co-op comparisons: Québec, Saskatchewan, and Canada, 2007

\begin{tabular}{|l|r|r|r|}
\hline & \multicolumn{1}{|c|}{ Québec } & \multicolumn{1}{c|}{ Saskatchewan } & \multicolumn{1}{c|}{ Canada } \\
\hline Top ranking Canadian cooperatives & $26 \%(13)$ & $14 \%(7)$ & -- \\
\hline Percent of Canadian population & 23 & 3 & -- \\
\hline $\begin{array}{l}\text { Top cooperatives (\%) to population } \\
\text { ratio }\end{array}$ & 1.1 & 4.7 & -- \\
\hline Revenue & $\$ 7.3$ billion & $\$ 6.8$ billion & $\$ 21.2$ billion \\
\hline Revenue per capita & $\$ 973$ & $\$ 6800$ & $\$ 645$ \\
\hline Assets & $\$ 2.6$ billion & $\$ 3.4$ billion & $\$ 8.5$ billion \\
\hline Assets per capita & $\$ 347$ & $\$ 3400$ & $\$ 258$ \\
\hline Full time employment & 18,281 & 4,184 & 30,341 \\
\hline $\begin{array}{l}\text { Full time per capita (total labour } \\
\text { force, seasonally adjusted) }\end{array}$ & .004 & .008 & .002 \\
\hline
\end{tabular}

Source: Co-operatives Secretariat (2007), Statistics Canada (2007) 


\section{Diamantopoulos (2011)}

These rankings also illustrate the long-range comparative structure of the two provinces' sectors-and the dramatically shifting base of co-operation in Saskatchewan. For example, Québec's dominant "old cooperatives," with one exception, are primarily agricultural. In contrast, Saskatchewan had lost its leading producer cooperatives to mergers and privatization by 2007. In fact, all seven leading Saskatchewan nonfinancial cooperatives are now affiliated with the second-tier Federated Co-operatives Limited. In short, while Québec successfully defended its first wave agrarian base as it diversified, Saskatchewan did not. Saskatchewan co-operators succeeded in establishing a second wave of consumer co-operation where Québec was unable to do so, but they failed to adequately diversify beyond retail, insurance, and credit in the urban milieu. As we will see, the rollback of agrarian producer co-operation had profound consequences for the Saskatchewan movement, liquidating both the economic and social base of co-operation's traditional bloc. Between privatizations and broader movement degeneration, the cooperative firm model itself experienced a major cultural and political setback.

\section{Financial cooperatives}

Comparing Saskatchewan credit unions and Québec's caisses populaires provides further insights (Table 3). Since the Canadian top-fifty list of credit unions excludes Québec, this table relies instead on provincial and Canada-wide statistics.

Financial cooperatives in Québec and Saskatchewan rank far higher than pan-Canadian norms for membership, branches, and assets per capita (nation-wide data on employment were not available). The 2007 numbers of credit unions per capita for each province were relatively even, at well over double the Canada-wide density. However, Québec led Saskatchewan by a wide margin in per capita membership, assets, and employment. This is likely the result of the historic lag in widespread adoption of the credit union model in Saskatchewan (MacPherson, 1979, p. 164) and the role of a strong, unified federation in Québec. Québec has a per capita advantage of $18 \%$ in assets, $20 \%$ in membership, and $40 \%$ in workforce.

\section{Table 3. Financial cooperative sector comparisons (credit unions and caisses populaires), 2007}

\begin{tabular}{|l|r|r|r|}
\hline & Saskatchewan & \multicolumn{1}{|c|}{ Québec } & \multicolumn{1}{c|}{ Canada } \\
\hline Members & 524,840 & $5,500,000$ & $10,846,512$ \\
\hline Members per capita & 52 & 72 & 33 \\
\hline Credit unions & 75 & 572 & 1,059 \\
\hline Credit unions per capita & .000075 & .000074 & .000032 \\
\hline Assets (\$M) & $\$ 11,248$ & $\$ 106,000$ & $\$ 209,190$ \\
\hline Assets per capita (\$) & $\$ 11,248$ & $\$ 13,789$ & $\$ 6,352$ \\
\hline Full Time Employees (FTE) & 3,000 & 35,493 & n.a. \\
\hline $\begin{array}{l}\text { FTE per capita (total labour } \\
\text { force, seasonally adjusted) }\end{array}$ & .006 & .009 & n.a. \\
\hline
\end{tabular}

Sources: Canadian Co-operative Association (2007a; 2007b); Credit Union Central of Canada (2008); Statistics Canada (2007; 2010a; 2010b) 


\section{Diamantopoulos (2011)}

Rather than a globalization-era divergence of movements, it may be more appropriate to suggest that financial co-operation in Québec benefited from a first mover advantage, which it continued to build on through the eighties, nineties, and into the twenty-first century. While the shake-out of the early eighties eliminated Québec's caisses entraide économique and the Ligue des caisses d'économie (Lévesque, 1990) (ironically strengthening movement unity around Desjardins), the Saskatchewan movement was wracked by intra-movement rivalries to consolidate territories. Forced to amalgamate and merge operations in the face of rural depopulation and new competitive threats, regional reorganization set off a "race to the beach" to consolidate market share, often at the expense of other credit unions (Lyons, 2007). In contrast, Québec's gigantic and unified movement can now better leverage its considerable economies of scale to build its competitive position against the banks, and expand across Canada.

While movement unity and strong central organization have provided Desjardins with a stable, dominant, and profitable platform for sponsoring wider movement initiatives, the scramble of Saskatchewan credit unions to consolidate expanding trading areas has undermined movement stability, unity, and cohesion. Like the loss of the Pool, Lilydale, and DairyWorld on the non-financial side of the ledger, consolidation of Saskatchewan's financial sector has done little to regenerate the provincial movement.

\section{Field effects: The foundations of movement degeneration and regeneration}

Established sector standing has played a driving role in structuring the cooperative fields of Québec and Saskatchewan. For, as Bourdieu (2005) argues, dominant firms can "define the regularities and sometimes the rules of the game" (p. 194) in a given field. While Saskatchewan failed to maintain its founding strength in agricultural producer co-operation, which was heavily dependent on the once-dominant grain economy, Québec's strengths continue to rest largely on this historic foundation. Supported by supply management, these are primarily dairy, pork, and poultry -led by Agropur and Co-opérative Fédérée. Its other major foundation is the financial sector, led by its Mouvement Desjardins. Saskatchewan's strengths, by contrast, have shifted decisively from agricultural production to insurance mutuals, consumer co-operation, and its credit union movement.

The shifting foundations of established sectors have also had consequences for emerging sectors. They have lent movement momentum and direction to the development of new sectors in Québec while fostering neglect and new sector stagnation in Saskatchewan. The role of Desjardins in Québec is illustrative of this. Among other things, Desjardins has backed new sectors such as the Inuit cooperative federation in the Arctic and funeral cooperatives (Girard, 1999), taken equity positions in worker shareholder cooperatives, bankrolled a research and development fund for emerging cooperative federations (Diamantopoulos, 2011), and managed a financing pool for regional and cooperative development (Mathews, 2001). These efforts all reflect a movement with deep pockets and increasingly developmental ambitions. Although reminiscent of the early role of the Pool in broadening-out Depression-era Prairie co-operation, the demutualization of the Pool, the consolidation of rural retail cooperatives, and a fragmented credit union movement have left a movement-building leadership vacuum in Saskatchewan. Emerging sectors such as community clinics, housing, or childcare cooperatives expect little support from their province's retrenching established sectors, or the under-resourced provincial apex organization-the Saskatchewan Co-operative Association.

The fates of dominant cooperative players have had diverging "field effects" across their provincial movements. On the one hand, steady, incremental growth in Québec's leading sectors-such as Co-opérative Fédérée, Agropur, and the Mouvement Desjardins-drove further expansion, confidence, and commitment to movement action. An expanding leading group thus reinforced overall sector expansion by providing policy-leverage, 


\section{Diamantopoulos (2011)}

resources, openness, and enthusiasm to new movement challenges. In Gramscian terms, the success of Québec's leading cooperative brands built the moral and intellectual authority of the cooperative alternative and its capacity for further expansion. It helped provide solid foundations for an historical bloc "from above," framed by the wider social movement resurgence of the social economy "from below" (Caillouette, 2004; Neamtan and Downing, 2005; Mendell, 2002; 2008; Lévesque \& Ninacs, 2000). In large part, co-operation forged a resurgent hegemony in the economic and social life of twenty-first century Québec by leveraging established sector strengths.

On the other hand, the collapse of agrarian producer co-operation-signalled by the privatizations of DairyWorld, Lilydale, and the Saskatchewan Wheat Pool-set a different pattern for the Prairie movement. The traditional agrarian base of the cooperative bloc had collapsed, with a weak movement transition to urban foundations beyond the established retail, insurance, and credit union sectors. Agrarian co-operation thus experienced a broad-based crisis of confidence, member loyalty, and movement agency-casting a long shadow over new development prospects across the cooperative field. A leading group of established cooperatives in crisis (and contention) reinforced broad-based sector contraction by scaling back movement resources for education, outreach, and development (Diamantopoulos, 2011), and retreating into a posture of siege management. In Gramscian terms, co-operation in Saskatchewan suffered a popular "crisis of authority"a sense of fatalistic resignation in the face of deregulated market forces and deepening investor-owned firm hegemony. Once a dominant feature of Saskatchewan's economy and society but deeply rooted in its agrarian movement, co-operation's traditional social base and claims to ideological hegemony were now eroding fast.

\section{Globalization: The cooperative provinces' paths diverge}

These twin movements for economic democracy expanded in waves over the better part of a century, before their growth trajectories so radically diverged in the post-eighties period (Fairbairn, 2005; Lévesque, 1990). Globalization hit both provinces hard but the nature of the cooperative movement response-and the scope and scale of their achievements-contrasted sharply. A startling development gap opened up, a trend best symbolized by the privatization of Saskatchewan's leading cooperative, the Saskatchewan Wheat Pool. The incorporation rate of new cooperatives-and the overall number of members, revenues, and assets-all grew rapidly in Québec. La belle province pulled decisively ahead of Saskatchewan.

\section{Table 4. The Saskatchewan - Québec development gap: Key indices for non-financial cooperatives, 1985 - 2005}

\begin{tabular}{|l|r|r|r|}
\hline Year & Saskatchewan & Québec & Canada \\
\hline $\begin{array}{l}\text { Rate of } \\
\text { associations growth }\end{array}$ & $+11 \%$ & $+152 \%$ & $+63 \%$ \\
\hline $\begin{array}{l}\text { Rate of } \\
\text { membership growth }\end{array}$ & $-8 \%$ & $+106 \%$ & $+98 \%$ \\
\hline $\begin{array}{l}\text { Rate of asset } \\
\text { growth }\end{array}$ & $-12 \%$ & $+273 \%$ & $+185 \%$ \\
\hline $\begin{array}{l}\text { Rate of revenue } \\
\text { growth }\end{array}$ & $-45 \%$ & $+160 \%$ & $+91 \%$ \\
\hline
\end{tabular}

Source: Co-operatives Secretariat $(1987,1992,1997,2002,2008)$ 


\section{Diamantopoulos (2011)}

\section{The association gap}

As Table 4 illustrates, the incorporation rate for non-financial cooperatives outside Saskatchewan was almost six times the equivalent rate in Saskatchewan from 1985 to 2005. In Québec, incorporations surged by almost 14 times Saskatchewan's rate. Moreover, while Québec posted consistent, cumulative gains in new cooperatives, Saskatchewan's growth slowed in the late nineties. In the first five years of the twenty-first century, the number of Saskatchewan cooperatives actually fell by $15 \%$. The divergence is even starker when inter-provincial trends in membership, earnings, and assets are compared. In all three categories, Saskatchewan's sector actually contracted from 1985 to 2005. Meanwhile, Québec posted triple digit growth rates in all categories.

\section{The membership gap}

Membership in Saskatchewan's non-financial cooperatives dropped by 8\% from 1985 to 2005. This contrasts sharply with Québec and pan-Canadian norms, where membership roughly doubled. In part, the stark reversal of co-operation's historic expansion in Saskatchewan reflects the corporate rationalization of agriculture, rural depopulation, the privatization of dairy and poultry, and the pruning of the rural retail store network. Mostly, it reflects the loss of 35,000 SWP members (Co-operatives Secretariat, 2004). Meanwhile the Québec cooperative movement developed diverse new worker-led sectors of movement activity including worker cooperatives, worker-shareholder cooperatives, and multi-stakeholder or "solidarity" cooperatives. Table 4 illustrates this widening membership gap.

\section{The asset gap}

The contrast in non-financial cooperative assets between the two provinces is greater still. From 1985 to 2005, Saskatchewan's asset base contracted by $12 \%$, as dairy and poultry facilities were transferred to new owners, abandoned rural stores were written off, and $\$ 700$ million in SWP assets were transferred to the investor-owned Viterra (Co-operatives Secretariat, 2004). During the same period the influx of new investment to its start-ups drove the Québec sector's assets to almost quadruple. Much of this new capital came from pools of "solidarity finance" developed since the eighties to finance cooperative and social economy enterprises. While neither the Saskatchewan movement nor its potential allies dedicated funds to cooperative development, in Québec the sector, labour movement, state, and even the private sector helped build up combined investments of $\$ 1.3$ billion for the social economy (Notwell, Reynolds, \& Katz, 2010). Table 4 illustrates this widening capitalization gap.

\section{The revenue gap}

Finally, as Table 4 also demonstrates, the starkest indicator of the reversal in sector growth in Saskatchewan can be found in declining revenues. The drop-off in this index over two decades is an unsettling $45 \%$. This compares to Québec's sector, which more than doubled its revenues. Once again, the loss of $\$ 1.4$ billion in SWP receipts (Co-operatives Secretariat, 2004) illustrates the magnitude of the impact of SWP's loss to the Saskatchewan sector. 


\section{Diamantopoulos (2011)}

\section{The development gap widens, $2000-2005$}

A further concern for Saskatchewan co-operators is the acceleration of declining memberships, assets, and revenues from 2000 to 2005 (Table 5). Since 2004 is the last year the Co-operatives Secretariat lists the SWP as a cooperative, its privatization accounts for much of this sector contraction. Set in motion in 1996 and formally completed in 2007, the SWP was a casualty of the farm crisis. It required huge capital investments to modernize but faced a run on member capital as a generation approached retirement. But its privatization also provided powerful reinforcement to the vicious downward spiral that engulfed globalization-era co-operation in Saskatchewan. In the wake of the collapse of the province's first, largest, and most iconic cooperative, the Saskatchewan Co-operative Association was also destabilized. It lost a leading member. It lost dues. It lost momentum. And it lost authority and influence with successive Provincial Governments (Diamantopoulos, 2011). The loss of the Pool was as damaging to Saskatchewan's movement as the loss of Desjardins might have been to Québec's movement.

\section{Table 5. The Saskatchewan - Québec development gap widens: Indices of Saskatchewan sector contraction, 2000 - 2005}

\begin{tabular}{|l|r|r|}
\hline $\begin{array}{l}\text { Saskatchewan } \\
\text { indices }\end{array}$ & $\begin{array}{c}\text { 20-yr trend } \\
(\mathbf{1 9 8 5 - 2 0 0 5 )}\end{array}$ & $\begin{array}{c}\text { 5-yr trend } \\
(\mathbf{2 0 0 0 - 2 0 0 5 )}\end{array}$ \\
\hline Number of co-ops & $+11 \%$ & $-15 \%$ \\
\hline Membership & $-8 \%$ & $-10 \%$ \\
\hline Assets & $-12 \%$ & $-59 \%$ \\
\hline Revenue & $-45 \%$ & $-62 \%$ \\
\hline
\end{tabular}

Source: Co-operatives Secretariat $(1987,1992,1997,2002,2008)$

Moreover, this body blow came together with demutualizations in dairy and poultry (Fulton and Hueth, 2009), and in the wake of the longer-range culling of movement-building tools like the Federated Co-operatives' Member Relations Division and the Co-operative Consumer newspaper that were discontinued in 1982 (Fairbairn, 1989); the Province's Department of Co-operation and Co-operative Development in Regina (Argue, 1992) and the movement's Co-operative College of Canada (Crewe, 2001) in Saskatoon, both wound down in 1987; and, the Pool's Western Producer newspaper that was privatized in 2002. This was a period of phased but decisive retreat from cooperative education and development. The provincial sector and state each ratcheted down their commitments to sustaining the historical bloc on which the cooperative movement rested. This would prove to have profound consequences as the globalization storm gathered at Saskatchewan's undefended borders.

The Québec sector also faced globalization-related threats and suffered wrenching losses. In the recession of 1982, for example, the federation of cooperative food stores collapsed. The following year, the federation of fishers' cooperatives folded (Girard, 1999). The recession also contributed to the failures of a credit union federation and several stores. This all reduced the number of federation members of the Conseil de la coopération du Québec, marginalized the organization, and ended the Conseil de la coopération du Québec publication Ensemble! (Lévesque, 1990). Québec's cooperative historical bloc was shaken and the legitimacy of the cooperative alternative itself was increasingly questioned. However, the Québec movement recovered and was transformed. Two decades après le déluge, Québec re-emerged as a world leader in cooperative development. Central to this surge were academic, state (Vézina, 2001), and social movement (Beaulieu, 2009; Neamtan, 2004, 2008) ties that helped drive a culture of social innovation toward new cooperative development. 


\section{Diamantopoulos (2011)}

Propelled by a modernizing leadership group - many of whom were veterans of the sixties Quiet RevolutionQuébec's historical bloc was effectively repaired, renovated, and expanded.

\section{The cooperative innovation gap}

While trends vary from category to category, the overall tendency is clear: development momentum moved decisively to Québec in the nineties. The case of the service cooperative sector provides evidence for this widening innovation gap. It also demonstrates the importance of broadening-out to effective movement renewal. For while old cooperative sectors may decline and some cooperatives will invariably fail, it is the development of cooperatives in new sectors of activity—often using new models and appealing to new constituencies-that hold out the promise of countervailing this sector contraction, and regenerating the movement.

Table 6. Comparative numerical (and percentage) growth in selected service cooperative sectors in Saskatchewan, Québec, and Canada, 1995 - 2005

\begin{tabular}{|l|r|r|r|}
\hline Sector & \multicolumn{1}{|c|}{ Québec } & \multicolumn{1}{c|}{ Saskatchewan } & \multicolumn{1}{c|}{ Canada } \\
\hline Total service co-op sector & $+486(+40 \%)$ & $+91(-15 \%)$ & $+263(+7 \%)$ \\
\hline Daycare & $+4(--)$ & $-5(-13 \%)$ & $+9(+11 \%)$ \\
\hline Pre-school & $--(--)$ & $-13(-17 \%)$ & $-41(-12 \%)$ \\
\hline Health clinics & $+8(--)$ & $--(--)$ & $+11(+122 \%)$ \\
\hline Recreation & $+19(+79 \%)$ & $-36(-19 \%)$ & $-31(-10 \%)$ \\
\hline Farmers' markets & $--(--)$ & $-2(-7 \%)$ & $-12(-24 \%)$ \\
\hline Arts and culture & $+25(+416 \%)$ & $+1(+25 \%)$ & $+32(+152 \%)$ \\
\hline
\end{tabular}

Source: Co-operatives Secretariat $(1997,2002,2008)$

The failure to expand service co-operation illustrates that globalization shocks did not spark another historic broadening-out of the movement, as the Great Depression had once mobilized Pool field-men and local committees to organize retail, credit, and later insurance sectors (G. Fairbairn, 1984; Fairbairn, 2005; MacPherson, 1979) across their rural networks. Instead, this period saw the retrenchment, then collapse of the Pool, and a degeneration of movement energy, organizing skills, and vision (Diamantopoulos, 2011). Prairie cooperation thus faced a sticky demographic succession from its traditional, rural base to a wider movement community.

\section{Explaining the cooperative development gap}

The above discussion has established the empirical reality of movement divergence since 1980. There is ample room for varied interpretation of these facts, but the evidence of a wide and widening gap is clear and overwhelming. In Saskatchewan, the evidence suggests that the collapse of the formerly leading segment of middle farmers in the traditional agrarian bloc (Stirling, 2001) was coupled with a failure to involve new social groups or the state in movement renewal efforts. In Québec, trends suggest a phased and successful transition 


\section{Diamantopoulos (2011)}

from traditionally rural and Catholic roots to a strong, broad, and expanding new social and economic base. With support from trade unions, urban social movements, the research community, and the state, the movement effectively restructured and repositioned. It constructed an expanded and highly articulated social economy bloc. To explain this divergence in the underlying social structure of cooperative economic action, the following sections are informed by historical research and interview findings.

\section{Saskatchewan: Agricultural consolidation and movement degeneration}

In Saskatchewan, the powerful new economic and political forces unleashed in the eighties drove federal politicians to move more aggressively: to deregulate, sign free trade agreements, dismantle farm subsidies like the Crow rate, abandon rail lines and rural post offices, and realign public policies and programs to "let the market decide." A century of agrarian agitation to protect farmers from unregulated capitalism was systematically rolled back (Conway, 2006). This project was as surely a counter-revolution against the gains of the early agrarian revolt as it was a defeat of Keynesianism and the welfare state. Nowhere was this clearer than in the federal government's laissez faire commitments through the international grain wars, while Europe and the United States continued to heavily subsidize their farmers (Pugh, 1991).

Globalization thus accelerated an already well-advanced process of agricultural consolidation. Caught in a costprice squeeze, farmers had to grow or die. Neo-liberal reforms sped up the trend to fewer, larger farms, and rural depopulation. Indeed, with the assistance of machinery and chemicals, the average Saskatchewan farm size nearly tripled from 1931 to 2001 (Stirling, 2001). Many squeezed middle farmers felt abandoned by their governments and at the mercy of the markets.

But they were being squeezed by more than increasing costs and declining prices; they were also being politically squeezed. The social cohesion and faith in collective action necessary to mount a spirited defence was also depleted as farmers drifted further apart-geographically and politically-in the sink or swim new market culture of corporate agribusiness. While barn-raisings had once provided the iconic image of agrarian socialist solidarity, the new spectacle of farmers bidding on former neighbours' land and machinery at foreclosure auctions better symbolized the survivalist ethos and angry right-wing populism that came to define the age. Globalization was both objectively liquidating the social base of agrarian co-operation by pushing middle farmers off the land and subjectively shifting the political culture against democratic and collectivist commitments. Co-operation's traditional historical bloc in Saskatchewan was collapsing, numerically and ideologically.

Global restructuring also drove cooperative sector retrenchment in Saskatchewan as rural retail, credit, and agricultural production and marketing networks now had to also ward off the incursion of better capitalized multinational competitors like Cargill and Wal-Mart. Unlike domestic competitors, these new challengers marshalled global market reach and economies of scale. Regionally rooted cooperatives had a great deal to fear from these new corporate Goliaths. A focus on the business-side modernization of exposed cooperatives was necessary, indeed urgent, in this context.

However, this narrow managerial focus also distracted cooperative leaders from re-building the movement's social base and cultural appeal. Rather than attempt to rally the membership and regroup the movement, established cooperative leaders had little alternative but to pull up the drawbridges. From 1996 to 2007, the number of cooperatives in Saskatchewan declined from 1,560 (Hammond Ketilson. Gertler, Fulton, Dobson, \& Polsom, 1998, 


\section{Diamantopoulos (2011)}

p. v) to about 1,200 , a decline of over $20 \%$ in just one decade (Canadian Co-operative Association, 2007b). Erosion of the movement's own defenses-in public education, membership development, new sector development, and a vibrant movement culture-would prove as lethal to the future of co-operation as the rise of neo-liberalism and its new multinational competitors.

This crisis context thus deepened already existing processes of agricultural consolidation, bloc dissolution, and movement degeneration. In particular, it exacerbated the principal-agent problem that set the immediate operational priorities of firm management against the wider interest in movement building. It was not in the business interests of any particular cooperative to invest in movement-building activities-such as member training, a cooperative press, reaching out to emerging publics, or supporting new cooperatives and new development campaigns. Similarly, state elites were captured by a bi-polar development model that oscillated between statist social democracy on the one hand and a free market fundamentalism on the other (Argue, 1992). Neither camp seemed to appreciate the importance of also creating a supportive climate for cooperative development.

However, cooperative education and movement building were still necessary to sustain member and staff loyalty, and to sustain the culture and development potential of the cooperative model against the maturing movement's own entropic tendencies. Strong movement identity, cohesion, and commitment were vital, if intangible, collective or "pool goods" which were necessary to avoid being crowded out of the market by the increasingly aggressive hegemony of the investor-owned firm model. Without sustained investments in rebuilding movement culture, start-up rates were bound to lag. Even well established cooperatives would be undermined. With the collapse of the province's major agrarian producer cooperatives, Prairie co-operation now faced a creeping cultural demutualization "from within" as well as competitive threats "from without."

To manage the crisis, leadership retreated into the uni-functional silos and conceptual frames of their own sectors. Their openness to emerging community needs and new cooperative development opportunities understandably withered - whether in childcare, housing, or in "Indian country'. With a "frozen" cooperative establishment, co-operation was unable to effectively diversify beyond the numerically and ideologically eroding social base of middle farmers. The movement's transition to new fields of activity-such as Aboriginal, workerled, or service cooperatives-was blocked.

In this context of a long-range farm crisis, imminent new market threats, and overall movement paralysis, several previously hidden weaknesses came into alarming view. These included the decades-long deterioration of movement-building infrastructure, including the culling of cooperative fieldworkers and cooperative education (Crewe, 2001); the long established over-reliance on a laissez-faire cooperative development model (Cooperatives Directorate, 1993; 1997); and the gradual disengagement with the state and social movements (Argue, 1992). The sudden force of market-driven restructuring accelerated the long-range erosion of these socio-cultural bases, upon which the mounting of a response would now be much less effective. This delayed the transition to a more demographically, regionally, and sectorally diversified movement in the wake of the globalization storm.

Just as deregulated markets accelerated the trend toward fewer and larger farms, and fewer and larger rural service centres, they also sped up the trend toward the degeneration of the progressive farmers' and cooperative movements. For grain, poultry, and dairy producers, this pincer movement would end in privatization. From 1980 to 2010, the farmer-led cooperative movement of the past was dying but a new, more broad-based movement of the future was still struggling to be born. 


\section{Diamantopoulos (2011)}

\section{Québec: The jobs crisis and movement regeneration}

It was persistently high unemployment that set the agenda for public and cooperative action in Québec in the eighties. Joblessness hit 14.2\% in 1983 (Statistics Canada, 2010a). In addition to business modernization strategies for established sectors "from above," pressure for movement modernization also thus emerged "from below"-to create jobs and expand social service provision.

An energetic and determined program of social mobilization—backed by the state, organized labour, and other social movements-successfully built new legal, financing, and technical assistance models (Vézina, 2001; Côté, 2007; Savard, 2007; Neamtan, 2008) and new development coalitions, including the Chantier de l'économie sociale (Beaulieu, 2009; Neamtan, 2004). This modernized bloc would regenerate the movement and expand into new fields of activity. For example, three "new co-op" sectors that include workers in governance-worker cooperatives, worker-shareholder cooperatives, and solidarity cooperatives-now account for a third of cooperative jobs in Québec (Clement, 2009).

Investments in movement-building, a program of sector-state partnership, wider social movement involvements, and continuous improvement through targeted research and development have each contributed to sector growth and expansion (Diamantopoulos, 2011). Far from the governing disinterest in development characteristic of the "old guard" that dominated the Conseil de la coopération du Québec (CCQ) in the seventies (Lévesque, 1990), development emerged as a legitimate, and leading, concern of the reconstituted new cooperative movement. In 2005, the CCQ (now re-named the Conseil québécois de la co-opération et de la mutualité or CQCM) even assumed management of the province's major development infrastructure, the network of eleven co-opératives de développement régional (CDR) first launched by the Province in 1985 (Savard, 2007).

This network played a leading role in mobilizing the movement to create new jobs, regenerating the movement in the process. It brought together over a thousand cooperatives and other organizations committed to cooperative development as members of the network's eleven second-tier, regionally-based development cooperatives. This mobilization network assisted the launch of over a thousand new cooperatives and created or maintained over 11,000 jobs in the past 15 years (La Fédération des coopératives de développement régional du Québec, 2010). By building inter-cooperative involvements at the regional level, the network built cross-sectoral movement cohesion, vision, and agency. From the bunkered frame of mature cooperativessteeped in the sectorally specific business demands of their own firms-the CDRs structured an historic reframing of cooperative action for development. The CDR network thus helped build a unified, modern, and developmental cooperative bloc on solid regional foundations-much as the caisses had once been organized around the Catholic parish network.

Federated alongside the established and other emerging sector federations within the CQCM, these regional development cooperatives also helped redress the principal-agent problem in movement deliberations. Their federation creates a voice for development, providing a check against the tendency to movement oligarchization and the degeneration of movement goals. In other words, these structural reforms of co-operation's historical bloc helped ensure effective movement modernization. As Vézina notes, by 2000, the apex organization once disinterested in development activity was "increasingly serving as a catalyst in penetrating new sectors when asked to do so" (2001, p. 144). From a reluctant development partner, the CQCM had been transformed into the vanguard of a developmental cooperative movement that was now strengthening and expanding the province's cooperative bloc. This reflected the concerted action of reformers within the movement as well as those outside the movement-in the unions, the state, and after 1996, the Chantier de l'économie sociale (CÉS), a 


\section{Diamantopoulos (2011)}

development-focused network of non-profits, social movements, and cooperatives (Lévesque \& Ninacs, 2000; Mendell, 2002; 2008; Neamtan, 2004; 2008).

The new reality of open, unprotected markets had radically disrupted the Québec movement. Several cooperatives and federations collapsed (Lévesque, 1990). Yet it entered the tumultuous eighties better prepared than Saskatchewan. Québec movement leaders turned the crisis into an opportunity, proposing a leading new role for co-operation in solving the intractable public policy problem of unemployment. Since the election of the sovereignist Parti Québécois (PQ) in 1976, the province had faced significant capital flight from Montréal to Toronto (Conway, 2004). When global markets were deregulated and restructured through the eighties, this experience gave it an intellectual and programmatic head-start on responding to the flight of manufacturing to low wage jurisdictions.

Several factors favoured a cooperative response to the globalization challenge. The PQ favoured rooted capital, which would not be a flight risk, and where French would be the language of work; it had successfully experimented with technical resource groups in housing and worker cooperative development in the seventies; urbanization and union organizing were advanced, particularly in Montréal; the labour movement was prepared to partner and to act (Beaulieu, 2009; Quarter, 1992); and there were strong extended social movement ties drawing the cooperatives into a wider social bloc forged in the crucible of the sixties Quiet Revolution. In short, a strong social movement coalition and developmental state favoured the cooperative model as a solution to the new problems of housing and unemployment. These fields of innovation and action were catalysts and templates for wider movement gains.

At the dawn of the globalization era, co-operation in Québec was beset by the degeneration of mature, highly institutionalized "old co-ops," divisions between the "old co-ops" and the "new co-ops," and ambivalence toward partnership with the state (Lévesque, 1990). This internal crisis for the movement was resolved by rebuilding a more broad-based and unified movement. Movement entrepreneurs built new social partnerships with the unions, civil society, the research community, and the state (Diamantopoulos, 2011). These efforts helped co-operation lead the social response to subsequent economic dislocations. Under the pressures of government debt and the state's inability to act unilaterally, co-operation came under strong pressure from community, trade union, academic, and state actors to reinvent itself to more rapidly meet the challenges of a provincial economy in transition. The start-up rate for cooperatives in Québec indicated a new vitality at the close of the twentieth century. Annual start-ups were on a very sharp incline, nearly doubling from 85 in 1995 to 169 in 2000. During this period, the number of jobs in non-financial cooperatives jumped $46 \%$, compared to $9.2 \%$ for the economy overall. From 2000 to 2006, jobs in the cooperative sector posted an additional $11 \%$ gain, net sales increased by $43 \%$, and assets spiked by 57\% (Finance, économie et recherche, Québec, 2003, pp. 16 - 20). This was also a movement characterized by significant innovation. For example, almost half the cooperatives created in 2006 were "solidarity cooperatives," a multi-stakeholder model introduced only a decade prior (Canadian Co-operative Association, 2007b). The intertwined structural crises of unemployment and a gridlocked cooperative movement in Québec in the early eighties had inspired a determined, innovative, and durable movement resurgence.

\section{CONCLUSION: THE PARADOX OF GLOBALIZATION ERA CO-OPERATION}

The above survey demonstrates that Québec's cooperative movement decisively expanded its position in the globalization era while Saskatchewan's suffered a dramatic contraction. Paradoxically, globalization-related dislocations both ended traditional, agrarian producer co-operation in Saskatchewan and sparked an epic sector expansion in Québec. 


\section{Diamantopoulos (2011)}

In both provinces, co-operation's traditional blocs were destabilized by globalization pressures. In Québec, urbanization, industrialization, unionization, and the articulation of new social movement and state partners to a modernized bloc were crucial to movement resilience. A strong urban base, actively supportive labour movement, engaged research community, and developmental state helped drive movement modernization and bloc renewal (Côté, 2007; Beaulieu, 2009; Vézina, 2001).

The CÉS represents Québec's emerging social economy movement. It is a network of groups committed to taking democratic social action to achieve economic power. It exists in an uneasy relationship with the more formal structures of the cooperative movement, the Conseil québécois de la co-opération et de la mutualité (Lévesque \& Ninacs, 2000). Nonetheless, this shifting and conflictual social economy bloc has consolidated the emergent hegemony of economic pluralism in Québec. The social economy sector is viewed as an increasingly legitimate and important third partner alongside the private and public sectors (Lévesque \& Ninacs, 2000; Mendell, 2000; 2008; Neamtan, 2008; Vaillancourt, 2009).

Neamtan (2004) emphasizes the strategic centrality of "cultural shifts" in this great leap forward. Indeed, cooperation's resurgent position within Québec's social economy bloc was preceded, as Gramsci (1977) might put it, by "an intense labour of criticism," a "diffusion of culture," and "a spread of ideas." Like past insurgencies against the status quo, the new co-operation, too, had to achieve the "ties of solidarity" and "unified consciousness" (p.12) necessary to its renewed vitality. Activists, researchers, developers, and policy-makers in Québec struggled to define a new cooperative project, organize viable campaigns, and win hearts and minds. They built popular mental preparedness for the necessary "cultural expansion" of co-operation-and other forms of social ownership. In short, it took aggressive communication and education as well as research, technical assistance, political alliances, and new institutional intermediaries to reassemble a viable historical bloc for this new co-operativism.

By contrast, the Saskatchewan movement's traditional base was radically and rapidly reduced by a wrenching agricultural consolidation in this period. While $61 \%$ of its residents lived on farms in 1931, this dropped to less than $12 \%$ by 2006 -reducing the province's farm population from a decisive majority to a very slim minority in the span of a lifetime (Statistics Canada, 2009). This reflected an economic shift to larger farms, but also the increasing marginalization of agriculture by the resource and industrial sectors. From 1984 to 1997 agriculture accounted for $10 \%$ or less of provincial gross domestic product, less than mining and oil extraction and less than half the value of industrial production (Stirling, 2001).

The collapse of the wheat province's traditional, farmer-led cooperative bloc left little energy and few resources to expand the movement's urban reach (Fairbairn, Hammond Ketilson, \& Krebs, 1977; Fairbairn, 2005; Diamantopoulos \& Findlay, 2007; Diamantopoulos \& Bourgeois, 2011). Most importantly, the traditional movement base among middle farmers was radically reduced and its leadership undermined by their struggles for survival. As Gramsci (1971b) put it in another case of blocked transition, "The crisis consists precisely in the fact that the old is dying and the new cannot be born: in this interregnum a great variety of morbid symptoms appear" (p. 276). With the declining hegemony of the historic left-agrarian bloc (Argue, 1992), the virtual dissolution of its traditional leadership base, and the progressive dismantling of education, communication, and movement-building structures (Diamantopoulos, 2011), Prairie co-operation plunged into an unprecedented, rapid, and perilous decline.

One final, important lesson from this tale of two movements is that it took a crisis in Québec-including cooperative failures, a major process of movement restructuring, and a concerted mobilization of civil society, 


\section{Diamantopoulos (2011)}

university-based, and state actors to meet pressing public needs-to set the stage for its recovery. In other words, it required the repair and reconstruction of its historical bloc, and the will to do so.

While the traditional era of producer-led agrarian co-operation in Saskatchewan is over-at least in dairy, poultry, and grains—a New Social Economy (Fairbairn et al., 1997; Fairbairn, 2005; Diamantopoulos \& Findlay, 2007; Silver, 2008; Diamantopoulos \& Bourgeois, 2011) is only in the early days of its struggle to emerge. Lessons from Québec will be useful as Saskatchewan struggles to re-invent its movement in radically new economic and social conditions; rebuilding on wider foundations; reaching out to an extended social movement family and the state; and adapting innovations—such as those developed by their Québécois cousins—to fit the emerging new development context. In no small measure, their task is to re-imagine and re-build a new, broader-based historical bloc that can drive this movement in the radically new social, economic, and political conditions of the twenty-first century.

\section{ACKNOWLEDGEMENTS}

The author is grateful to his interview sources and for insightful feedback on an earlier iteration of this work from April Bourgeois, Brett Fairbairn, Isobel and Len Findlay, Michael Gertler, Lou Hammond Ketilson, Tim Quigley, Larry Haiven, ANSER-J editor Peter Elson, and the anonymous reviewers. This research project would not have been possible without the support of the Centre for the Study of Co-operatives, University of Saskatchewan and Co-operation Works!, which supported my travel to Québec on a study tour in 2007. The University of Regina supported my fieldwork in 2009. I relied on important financial assistance from the Social Sciences and Humanities Research Council of Canada and the Queen Elizabeth II Scholarship in Parliamentary Studies. I am also grateful to Concentra Financial for their support of the Dennis Lyster Research Bursary and this work. The Canadian Association for Studies in Co-operation aided me with the Lemaire Co-operative Studies Award and the Alexander Laidlaw Fellowship.

\section{REFERENCES / BIBLIOGRAPHIE}

Argue, G. (1992). The Department of Co-operation and Co-operative Development, 1944 to 1987. Unpublished Masters thesis, University of Regina, Regina, Saskatchewan.

Beaulieu, L. (2009). A new economic paradigm for the challenges of sustainable development. In Harrisson, D., Szell, G. \&

Bourque, R. (Eds.), Social innovation, the social economy and world economic development (pp. 19-28). Frankfurt am Main: Peter Lang.

Bourdieu, P. (2005). The social structures of the economy. Cambridge: Polity Press.

Caillouette, J. (2004). The community and social economy movement in Quebec: Development and recognition, 1989 - 2003. Montreal: Centre de recherché sur les innovations socials. Canadian Co-operative Association. (2007a). Co-ops in Saskatchewan. URL: http://www .coopscanada.coop/assets/firefly/files/files/pdfs/ProvAndSectoralProfiles/Saskatchewan_co-ops jun07.pdf [June 5, 2011].

Canadian Co-operative Association. (2007b). Co-ops in Québec. URL: http://www.coopscanada.coop/assets/firefly/files/files/pdfs/ ProvAndSectoralProfiles/Quebecco-opsapr08.pdf [June 5, 2011].

Carroll, W. \& Ratner, R. (1989). Social democracy, neo-conservatism and hegemonic crisis in British Columbia. Critical Sociology, 16, $29-53$.

Clement, M. (2009). Co-operative development in Québec. Québec: Développement économique, innovation et exportation.

Coleman, W. D. (2004). Globalization and co-operatives. In Fairbairn, B. \& Russell, N. (Eds.), Co-operative membership and globalization: New directions in research and practice (pp. 3-17). Saskatoon, Centre for the Study of Co-operatives, University of Saskatchewan.

Conway, J. F. (2004). Debts to pay: The future of federalism in Québec. Toronto: James Lorimer and Company.

Conway, J. F. (2006). The West: The history of a region in confederation. Toronto: James Lorimer and Company. 


\section{Diamantopoulos (2011)}

Co-operatives Directorate. (1993). Building effective partnership: The co-operative sector and the government in Saskatchewan. Regina: Saskatchewan Economic Development.

Co-operatives Directorate. (1997). Support for the development of co-operatives: Discussion paper. Regina: Saskatchewan Economic and Co-operative Development.

Co-operatives Secretariat. (1985-1994). Co-operation in Canada. Ottawa: Co-operatives Secretariat.

Co-operatives Secretariat. (1995-2007). Co-operatives in Canada. Ottawa: Co-operatives Secretariat.

Co-operatives Secretariat. (2004-2009). Top 50 Non-financial Co-operatives in Canada. URL: http://www.coop .gc.ca [June 5, 2011].

Côté, D. (2007). Best practices and co-operative development in Québec. In Emmanuel, J. \& Cayo, L. (Eds). Effective practices in starting co-ops: The voice of Canadian co-op developers (pp. 97 - 116). Victoria: New Rochdale Press.

Credit Union Central of Canada. (2008). Fourth Quarter 2007. System results. URL: http://www.cucentral.ca/4thq07 revised 29april08 [June 5, 2011].

Crewe, J. (2001). "An educational institute of untold value:" The evolution of the Co-operative College of Canada 1953 - 1987. Saskatoon: Centre for the Study of Co-operatives.

Develtere, P. (1996). Co-operative development: Towards a social movement perspective. Saskatoon: Centre for the Study of Cooperatives.

Diamantopoulos, M. (2011). Globalization, social innovation and worker co-operatives: A comparative analysis of co-operative development in Saskatchewan and Québec, 1980-2010. Unpublished doctoral dissertation, University of Saskatchewan.

Diamantopoulos, M. \& Bourgeois, A. (2011). Worker co-operative development in Saskatchewan: Problems, prospects, and proposals. Saskatoon: Community University Institute for Social Research.

Diamantopoulos, M. \& Findlay, I. (2007). Growing pains: Social enterprise in Saskatoon's core neighbourhoods. Saskatoon: Community University Institute for Social Research.

Fairbairn, B. (1989). Building a dream: the co-operative retailing system in western Canada, 1928-1988. Saskatoon: Western Producer Prairie Books. Fairbairn, B. (1994). The meaning of Rochdale. Saskatoon: Centre for the Study of Co-operatives.

Fairbairn, B. (2001). Social movements and co-operatives: Implications for history and development. Review of International Cooperation, 94, 24-34.

Fairbairn, B. (2005). Canada's co-operative province: Individualism and mutualism in a settler society, 1905 - 2005. Saskatoon: Centre for the Study of Co-operatives.

Fairbairn, B., Hammond Ketilson, L., \& Krebs, P. (1997). Credit unions and community economic development. Saskatoon: Centre for the Study of Co-operatives.

Fairbairn, G. (1984). From Prairie roots: The remarkable story of the Saskatchewan Wheat Pool. Saskatoon: Western Producer Prairie Books.

Fédération des coopératives de développement régional du Québec (2010). Portrait. URL: http://www.fcdra.coop/index.php?id=41 [October 25, 2011].

Finance, économie et recherche, Québec. (2003). Horizon 2005: Co-operative development policy. Québec: Ministere des Finances, de I Économie et de la Recherche, Québec.

Fulton, M. \& Hueth, B. (2009). Co-operative conversions, failures and restructurings: An overview. Journal of Co-operatives, 23, i-xi.

Girard, J.P. (1999). An identity to be asserted, a gap to be filled: Historical overview of the co-operative movement in French Canada: 1850 - 2000. Montréal: Chaire de coopération Guy-Bernier/Université du Quebec a Montréal.

Gramsci, A. (1971a). The state and civil society. In Hoare, Q. \& Smith, G. N. (Eds.) Selections for the Prison Notebooks (pp. 206-276). New York: International Publishers.

Gramsci, A. (1971b). The modern prince. In Hoare, Q. \& Smith, G. N. (Eds.) Selections for the Prison Notebooks (pp. 123-205). New York: International Publishers.

Gramsci, A. (1977). Socialism and culture. In Hoare, Q. (Ed.). Selections from political writings, 1910-1920 (pp. 10-13). Minneapolis: University of Minnesota Press.

Granovetter, M. (1992). Economic action and social structure: The problem of embeddedness. American Journal of Sociology, 91(3), 481-510. 


\section{Diamantopoulos (2011)}

Hammond Ketilson, L., Gertler, M., Fulton, M., Dobson, R. \& Polsom, L. (1998). The social and economic importance of the cooperative sector in Saskatchewan.

Saskatoon: Centre for the Study of Co-operatives. Lévesque, B. (1990). State intervention and the development of co-operatives (old and new) in Quebec, 1968 - 1988. Studies in Political Economy, 31, 107-139.

Lévesque, B. \& Ninacs, W. (2000) The social economy in Canada: The Québec experience. In Shragge, E. \& Fontan, J. M. (Eds.). Social economy: International debates and perspectives (pp. 112-129). Montreal: Black Rose Books.

Lipset, S. (1959). Agrarian socialism: The Co-operative Commonwealth Federation in Saskatchewan, a study in political sociology. Berkeley: University of California Press.

Lyons, M. (2007). First-Sask, Affinity credit unions propose merger. Star-Phoenix. URL: http://www.canada.com/saskatoonstarphoenix/ story.html?id=ecb8340f-fe42-4201-b450-b92fd5e3bc6d\&k=60013 [September 20, 2011].

MacPherson, I. (1979). Each for all: A history of the co-operative movement in English Canada, 1900-1945. Macmillan of Canada, Toronto.

Marchak, P. (1991). The integrated circus: The New Right and the restructuring of global markets. Montréal: McGill-Queen's University Press.

Mathews, R. (2001). Mutuals in regional economic development: Móndragon and Desjardins. In Bichall, J. (Ed.) The new mutualism in public policy (pp. 155-170). London: Routledge.

Mendell, M. (2008). The social economy in Québec. Saskatoon: Centre for the Study of Co-operatives.

Mendell, M. (2002). The social economy in Québec: Discourses and strategies. In Bakan, A. B., Leyes, C. \& MacDonald, E. (Eds.), Critical political studies: Debates and dialogues from the left (pp. 319-344). Montréal: McGill-Queen's University Press.

Neamtan, N. (2004). The political imperative: Civil society and the politics of empowerment. Making Waves. 5(1), 26-30.

Neamtan, N. (2008). A new beginning for social economy in Québec: the governmental action plan for collective entrepreneurship. Making Waves, 19(4), 8-10.

Neamtan, N. \& Downing, R. (2005). Social economy and community economic development in Canada: Next steps for public policy. Chantier de l'Économie Sociale, Montréal.

Notwell, J., Reynolds, J. \& Katz, M. (2010). Finance and Investment. Issue paper \#1, 2010 National Summit for a People-Centred Economy. URL: http://www.ccednet-rcdec.ca/sites/ccednetfiles/ccednet/pdfs/1-Finance_and_Investment.pdf [June 5, 2011].

Pugh, T. (1991). Cultivating the corporate agenda. In Biggs, L. \& Stobbe, M. (Eds.) Devine rule in Saskatchewan: A decade of hope and hardship (pp. 67-80). Saskatoon: Fifth House Publishers.

Quarter, J. (1992). The social economy. Halifax: Lorimer.

Rural and Co-operative Secretariat (2010). Overview of Co-operatives in Canada: 2007. URL: http://www.coopscanada.coop Ipublic html/assets/firefly/files/files/Co-op overvierw 2007.pdf [June 5, 2011].

Savard, C. (2007). Co-operative practices and the experience of a regional development co-operative. In Emmanuel, J. \& Cayo, L. (Eds.). Effective practices in starting co-ops: The voice of Canadian co-op developers (pp. 239 - 256). Victoria: New Rochdale Press.

Silver, J. (2008). The inner cities of Saskatoon and Winnipeg: A new and distinctive form of development. Canadian Centre for Policy Alternatives, Manitoba.

Statistics Canada. (2010a). Labour Force Historical Review 2009 (Table 086). Ottawa: Statistics Canada, 2010 (Cat. No. 71F0004XVB).

Statistics Canada. (2010b). Population by year, by province and territory. Table 051-0001. URL: http://www40.statscan.gc.ca/101 Icst01/demo02a-eng.htm [June 5, 2011].

Statistics Canada. (2009). Saskatchewan's farm population changes over a lifetime. URL: http://www.statscan.gc.ca/cara2006/agpop/sk-eng.htm [June 5, 2011].

Statistics Canada. (2007). Labour force characteristics by province, seasonally adjusted. URL: http://www40.statscan.gc.ca/101/cst01 /1fss01a-eng.htm [June 5, 2011].

Stirling, R. (2001). Transitions in rural Saskatchewan. In Leeson, Howard A. (2001) Saskatchewan politics into the twenty-first century (pp. 319-336). Regina: Canadian Plains Research Center. 


\section{Diamantopoulos (2011)}

Vaillancourt, Y. (2009). The social economy in Québec and Canada: Configurations past and present. In McMurtry, J.J (Editor). Living economics: Canadian perspectives on the social economy, co-operatives, and community economic development (pp. 57-104). Toronto: Edmond Montgomery Publications.

Vézina, M. (2001). Québec. In Lindquist, E. A. \& Restakis, J. The co-op alternative: Civil society and the future of public services (pp. 135-152). Ottawa: Institute of Public Administration of Canada and the Canadian Co-operative Association.

\section{About the Author / l'auteur}

Mitch Diamantopoulos is Assistant Professor and Department Head of the School of Journalism at the University of Regina as well as Centre Scholar with the Centre for the Study of Co-operatives at the University of Saskatchewan, in Saskatoon. Email: Mitch.Diamantopoulos@uregina.ca 